very small incision. Immediately upon delivery the vaginal incision was closed with silver wire sutures, which took in the walls of the ureter. Some hemorrhage occurred in the anterior cul-de-siac, and as it was not desired to take any more time a few elamps were left on the vessels. A gaume drain wits put in. 'The whole operalion took ten minutes, and the stone was delivered in five minutes. The convalesenese was not remarkable and there was no fistulat. The ureter has remained pervious since the operation for both ureters have been atheterized since. 'The stone was a very large one and it combl not possibly have been passed por vias naturales. It weighed in the dry state $7 \mathrm{dg}$. and it wats $1 \mathrm{~cm}$. long and nearly $1 \mathrm{~cm}$. wide at the widest part. It consisted of phosphiate of lime.

At the time this operation was done I was not aware that Doyen * had originated an almost similar operation for the remoral of stones in the ureter. Doyen's operation, however, differs in a number of essentials. He incises the anterior cul-de-sac, and the ureter is exposed in the culde-sace. 'Then the stome is removed through the? cul-de-sace itself and not through the vathinal wall. The operation teminates by suture of the ureteral walls and a drain is left in the oulde-sac. 1)oyen's operation must take a great deal of time on aceomut of the technical difliculties, and a fistula must be more serious in the anterior cul-rle-sar: lhan in the vagima, should one result. The advantages of the operation as performed moon my patient are olsvious. The technique is simple. Hemorrhage is moter perfect control. It is very rajuid. I feel certain that very high stones an be pushed down and brought within reach. If listula results the consequences will not he as serions as they are when the sacral, the reetal, or the J)oyen method is employed, and oporations for fistula are rasier through the vagina than through the other routes mentioned. The ureteral and the vaginal walls can be sutured en masse with suceess. As the ureter in these cases is always dilated, this suturing is less diflicult than it appears on first sight. If it leaks sulsequently, the leakage will take place between the stitehes and no harm will result. (of all the advantages gained, that, with reference to time is the most important. 'These patients are almost always desperately ill, and time is an element somelimes not suftiricutly consirlered.

\section{Mecoical grogregs.}

\section{REPORT ON PATHOLOGY.}

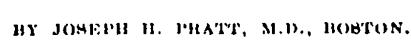

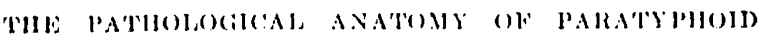
livisir.

Wrats and Siontt ${ }^{1}$ report a fatal catse of paratyphoid fever. ()nly four other instances have been recorded in the literature althongh nearly a hundred cases of the diseaso have heen recognized during the past six years. 'The chief

*H. Morris. Surgical Disenses of the Kidney and Ureter. Iondon. 1901 , Vol. 11 . nuge 530 .

1 Journal of Infections l)imentes, 1961.4, i, 1) 72. clinical features in the case studied by the writers was the continued fever which reached $104^{\circ}$ on the day of admission to the hospital. 'The pulse was somewhat accelerated and dicrotic. A few rose spots appeared on the abdomen and the spleen was palpable. Intestinal hemorrhage occurred early in the disease. The patient died during the fifth week of illness. Agglutination tests with the typhoid bacillus were negrative. Infortunately the reaction of the blood with paratyphoid hacilli was not tested. At the antopsy a paratyphoid bacillus was obtained from the spleen and kidney and there can be little, if any, doubt that the case was one of paratyphoid infection. The organism produced a terminal alkalinity in milk and hence belongs in group is of Buxton's classification, although the authors place it in group $a$.

The spleen weighed $400 \mathrm{gm}$. and was very soft. The lymphatic apparatus of the intestine was not involved and the nesenteric lymph nodes preserved their normal size. Numerous irregular superficial ulcers were fomnd in the ileum just ahove the ileo-cecal valve. 'Jhere was no infiltration around the uleers and they resembled those of dysentery much more thin those of typhoid. Similar uleers occurred in the case reported by Iucksoh. Intestinal lesions were alsent in the three other fatal cases.

The ahsence of proliferation and phagocytosis in the lymph nodules, which Mallory has shown to be the characteristic intestinal changes in typhoid fever, as well as the absence of any involvement of Peyer's patches in paratyphoid fever indieate, as the authors state, that there is some essential if obscure biological difference between the typhoid and paratyphoid bacilli. The anatomical picture of paratyphoid fever is that of a septicemia associated with splenic enlargement and ocensionally with non-specific: uleers in the intestine.

\section{THE GENESIS (IF HI,OOD PLA'Tlis.}

The opinion held by many pathologists that. blood plates are products of red blood corpuscles is largely based on the olsservations of Wlassow made in Viegler's laboratory some years ago. This investigator found that when blood was treated with a solution of mercuric chloride (saturated aqueous solution of mercuric chloride 10 parts, distilled water 50 parts) there were quickly formed from the erythrocytes red bodies with sharp outlines which gradually became transformed into colorless structures resembling blood plates. (Other rengents acted similarly on the erythrocytes. Wlassow observed that these bodies like the blood plates were stained with certain aniline basic dyes nud he regarded the two as identical and clnimed that this experiment showed that the blood plates are not independent cellular elements of the blood but are formed from the erythrocytes.

Sacerdotti ${ }^{2}$ states that the bodies described by. Wlassow are not blood plates and morphological differences exist between the two struc-

\footnotetext{
"Anntomischer Anzoiger, xvii, p. 249.
} 
tures, although they appear similar at the first glance. The little knols on the erythrocytes are never flattened, while the blood plates are flat. The former are homogeneons and freguently tinged with hemoglobin and thereby differ from the blood plates which present a granular appearance and are always colorless. Another difference was shown by treating a mieroscopical preparation prepared by Wlassow's method with a dilute solution of acetic acid, preferably a $5 \%$ solution. The small globular knobs and the red blood corpuscles vanish while the bood plates remain and their gramular appearanee beromes more distinet.

sacerdotti performed another experiment. He defibrinated blood, in order to remove all the blood plates and then mixed the blood with sublimate solution. After the small globular bodies were formed acetic acid was added. The erythroeytes and globules disappeared and nothing renained which bore any resemblance to blood plates. If the action of the aretic acid was studied under the microseope it was seen that Wlassow's globules first swelled, gradually paled and finally disappeared. 'The erythrocytes were more resistant and for a time a crater marked the site of the dissolved knol). With such differences in form and nature existing between Wlasssow's bodies and the plates, how ean the view be entertained, says the author, that the blood plates are derived from the erythrocytes?

Schneider ${ }^{3}$ under Arnold's direction has repeated sacerdotti's experiments. When a drop of blood is mixed with Wlassow's fluid shanges in the erythroeytes oceur with great rapidity. At the moment of contact the erythrocytes become smaller and globular. They lose their elasticity entirely and appear completely fixed. A few of the fixed elements appear as bell-shaped bodies with a concavity on one side. The author does not agree with Weidenreich that the normal form of the erythrocytes is bellshitped. The majority of the erythrocytes appear as spherical structures. A portion of many of the corpuscles is finally granular and eolorless or faintly tinted with hemoglohin. The ehief mass of the hemoglobin is eollected at the other pole of the erythrocyte where the peculiar little knob is attached. This little body is usually spherieal. If two are present they are rarely of equal size. 'They vary from one fif th to one third of the size of the erythrocyte. Most of the horlies contain hemoglobin and are homogeneous. Transitions were seen between these and quite colorless, slightly granular forms. Some were only attached to the erythrocyte by a threal-like connection, but no free bodlies wore seen, such as Haximow has described. Sichneider calls attention to the fact that both Whassow's bodies and hood plates stain similarly with mothyl violet and gentian violet. But he agrees with sacerdotti that the plates resist the action of clilute acetie acil while the structures formed from the erythrocy tes by the mercuric chloride solution are quickly dissolved. Schneider prints out that

3 Virchow's Archiv., 1003, slxxiv, p. 294. red blood corpuscles have been shown to contain mucleod material and he asserts that a part of the erythrocyte is not dissolved by the acetic acid but remains as a shadow and concludes from this that sacerdotti's experiment does not prove that blood plates camnot be formed from the erythrocytes.

On agar preparations, prepared by leetjen's method and containing 2 to $10 \% \mathrm{Na} \mathrm{Cl}$, the anthor states that hood plates are formed in large numbers from the red blood eorpuseles and that some resist acetic acid. As the result of his studies he concludes that the blood plates are not independent cells but simply cell derivatives. The great majority of the plates of normal blood according to Schneider arise from the erythrocytes, but some are derived from the leucocytes. Most of the plates possess nuclear substance, which can be demonstrated by certain staining methods and the nuclear substance is the cause of their resistance when brought in contact with dilute acetic acid.

A. EXPERIMLN'JA, STUDY OF THE: NO-(ALALD FATTY DEGENIRATION.

Fischler ${ }^{4}$ arrives at the following eonchusions based on a study of the fat in kidney infarets experimentally produced in rabbits.

The appearance of visible fat in cells, as woll in the so-called fatty degeneration, as in fatty infiltration is dependent not alone upon a certain condition of the cell, but upon factors outside of the cell.

Some circulation must be maintained although it need not be complete, of the bloorl, lymph or diffusion stream, or fatty metamorphosis will not oceur.

The most essential condition for the appearance of fat is the life of the cell. Dead cells do not indergo fatty metamorphosis. 'The experiments summarized in this study add nothing to the support of the theory that fat can originate from the eell proteids. Without doubt the presence of fat within the cell ean be due to a great variety of conditions.

THE DIAGNOSTIC VALUE OF H,OOD) CUITURES,

Hecktoen "records a ease in which the concurrence of searlet, fever and typhoid fever was observed. The patient was suddenly taken ill with nausea, headache and pain in the limbs. 1)eglutition became difficult and painful. On the day following the onset a rash developed on the neek and body and spread to the face and extremities. When arlmitted to the hospital on the fourth day of the disease there was a deep subeuticular flush with raised points. The tongue had the "strawberry" appearance seen in searlet fever and the tomsils were swollen. A culture from the blond made the next day yielded a pure growth of the typhoid bacillus and the blood gave a positive Grinhaum-Widal reaction. Typical scarlatinal desquamation occurred. The temperature fell to normal about the twentyfirst day. The elinical features seem distinetive 
of scarlet fever but, as the author admits, absolute evidence as would be furnished by the clemonstration of the causative agent is lacking. The oceurrence of desfuamation is regarded as strongly supporting the diagnosis of scarlet fever. 'I'wo eases of typhoid ferer associated with early angina and erythema were observed in which there was no exfoliation. In both instances the typhoid hacillus was ohtained from the blood during the first week. 'The author emphasizes the almost constant presence of the typhoid bncillus in the hlood in the early stages of the disease and the importance of blood eultures to set.tle promptly the diagmosis of typhoid fever in such puzzling eases as the ones reported.

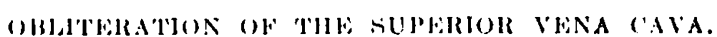

Althomgh eompression of the superior vena cava is not very uncommon in cases of aortic aneurism and mediastinal tumors, instances of complete obliteration of the vessel with the establishment of rollateral circolation are, aceording to ()sler." very rare. In a seareh of the literature he foumd only twenty-nine eases of complete obliteration of the superior vena cava.

I. 'Thrombosis due to disease within the vein, 10) ases. Simple phlebitis seemed to have been the eause of the thrombus formation in $s$ of these: one was a propagated thrombus from the periphery (Duchek), and one was due to tuber(ulous cindophlebitis (Banti).

'The majority of the rases helonged in the second colass.

1I. J)isease outside of the vein, 1!) rases, groujed as follows: (a) tuberemlosis, 4 rases; (b) mediastinitis, 4 eases; (c) aneurism, 4 eases: (d) syphilis, 3 rases: (e) periantitis, 2 cases: (f) carcinoma, 1 case; (g) fibroma, 1 case.

()sler divides the atses relinically into two gromps. In one gromu after years of (ompletely effected collateral circulation and good health the symptoms set in arutely. In the other group the symptoms of venous obstruetion are constantly present although the individual may enjoy a fair measure of health.

Osler reports an instance of ocelusion of the superior vena cava from compression by enlarged mediastinal lymph nodes in Hodgkin's disease and another ease in which the diagnosis of fibroid obliteration of the superior vena eava was marle during life. The seeond ase presented many interesting and mosual features. When first secul the pationt eomplaimed of dyspnea and swelling of the noek. There was gradual distention of the silperficial thoracic and epigastric veins. The case was regarded during the first year as probably one of intra-thoracic tumor, but the alsenese of all signs of ancurism and of enlargement of the lymph nodes, the megative result of the x-ray examination, the slow course of the discase. led to the correct diagnosis. Symptoms of phthisis pulmommm developed and tubercle bacilli were found in the sputum. At autopsy the left jugular, both innominate veins, and the upper portion of the

\footnotetext{
- Bulletin of the Johns Hopkins Hospital, 1903, xiv, p. 163.
}

superior vena cava were found converted into a dense thick cord. The superior vena cava was patent within the pericardium from the point. where it received the dilated azygos vein (1) the heart. There was tuberculous caries of the last cervical and the two upper thoracic vertobra. The fibrous tissme about the diseased portion of the spine was contimons with that ahout the innominate veins.

\section{THF RELATION OF MYEIAN 'TO WAT'Y}

\section{METAMOHPHOSIS.}

According to Kaiserling and Orghler, ${ }^{7}$ myelin (Irops resemble fat morphologically only. They are stained light gray hy osmic acid, never coloring as intensely as fat. With sudan III and scharlach $R$ they assume a red hue. The osmic acid preparations of myelin, unlike fat, are decolorized by xylol, chloroform and oil of bergamot. They differ from fat in being double refractive. In hardened tissues the double refration of the myelin is lost. These myelin droplets were found in fatty metamorphosis of the cells of intima of arteries, particularly the norta, in an amyloid kidney, and a great white kidney of ehronic Bright's disease, in the epithelial colls of the pulmonary alveoli, in pneumonia and tuberculosis, and in the bronchial secretion. also in the corpus luteum of the ovary and in the eortex of the arbenal and the retrogressive metamorphosis of the thymus gland.

Myelin granules were not found in the henrt, in fatty infiltation of the liver, in the normal fat deposits of the body, in colostrum, in fumetioning mammary glands, or in four cases of fatty motamorphosis of the kidney.

Fichmidt and Muller obtained from the myelin drops of the sputum protargon, a highly iomplex body, but not a fat. By the breaking I]) of protargon, lecithin and cerebrin are formed.

ORICIN OF EOSINOPHIL LEUCOCYTLS.

(O)ie" has made an experimental study of the eosinophile cells in the blood and tissues of guinea pigs and the relation of these cells to mutrition. 'This investigation lends support to bhrlich's view that the eosinophiles are derived wholly from the bone marrow.

In the mucosa of the intestinal tract and airpassages and in other tissues of the guinea pig oceur eosinophilic polymorphonuclear lencosytes identical with those of the blond. In the bone marrow alone monomuclear eosinophiles are found. These undergo mitosis, and transition forms between them and the eosinophiles of the blood ean also be demonstrated in the bonemarrow. When the eosinophiles of the blood become increased the number of eosinophilic myelocytes was far greater than normal and proliferation of these eells was more active. The blood vessels of tissues in which accumulation of eosinophiles occurred contained in certain instances a demonstrable increase in the eosinoplinile leucocytes.

7 Virchow's Archiv, clxvii, p. 296.

"American Journal of the Alerlicul Aciences, 1904, exxvii, p. 217. 
Starvation eaused a diminution in the number of eosinophiles in the blood. A temporary loss of weight was accompanied by an increase while a gain in weight led to a deorease of the eosin(1) hiles.

\section{THE PRIMARY ACTION OF THE TUBHRCLA BACHLUAS.}

Baumgarten has maintained that the production of miliary tubereles and diffuse tulereulous tissue is the result of a direct irritation by the tuberele bacillus of the fixed cells of the part. This irritation causes the cells to proliferate.

Aceording to Weigert's well-known theory such an explanation would not, we tenable. The cause of the proliferation of the cells should be sought rather in an injury to the tissue which removes the inhibitory force that normally holds in check the power of growth of the cells. Neither Baumgarten nor the other writers have concerned themsclies with the existence of such a primary injury.

Wechsherg "studied this problem in Weigert's laboratory. Suspensions of tuberele bacilli were injected into the ear veins of rabbits. The animals were killed at different periods ranging from six hours to twelve days and the lungs hardened and sectioned.

At the end of six hours the blood-vessels showed in places a loss of their endothelium as well as a marked destruction of their elastic (ibers. Gromps of bacilli lay in the lumina of the vessels surrounded by polynuclear leucoeytes. After twenty-four homrs epithelioid cells were found. The destruction of elastic tissue was the more extensive the longer the duration of the infection.

Wechsberg concludes that the tubercle bacillus destroys the fixed cells and the intercellular tissue by its toxic action. It then injures the new formed cells so that they are unable to prodince connective tissue and blood-vessels. The formation of giant cells indieates that the protoplasm of the proliferated cells is only injured in part. linally the new formed cells become entirely destroyed and the stage of caseation is reached.

Recently an elaborate monograph on the mode of action of the tubercle bacillus has been written by Herxheimer, ${ }^{10}$ one of Weigert's assistants. It is, in a sense, a continuation of the stucly begun by Wechsberg. 'Tubercle bacilli suspended in fluid were injected into the trachea of rabbits and guiner pigs. 'The animals were killed at different intervals, from one-half hour to seven weeks after the injection. The staining methol, which gave the best results, was a combination of Weigert's elastic tissue stain and anilin-watermethyl-violet. 'The tuberele bacilli were colored blue and stood out sharply upon the real background.

(1) Stain the sections in lithium camine several minutes.

(2) Differentiate in 1\% hydrochloric: arial alcohol several hours.

- 'Ziegler's Beitritge, 1001, xxix, p. 203.

10 'Ziegler's Beitruge, 1903, xxxiii, p. 303 .
(3) Stain in Weigert's elastic stain one hour.

(4) Wash rapidly in acid alcohol.

(5) J)ifferentiate (puickly in $96 \%$ alcohol.

(6) Stain in anilin-methyl-violet several hours in the cold.

(7) Differentiate in acid alcohol and in $96 \%$ alcohol.

(\$) Dehydrate in absolute aloohol.

(9) Clear in xylol.

(10) Mount in balsam.

In order to remove the violet color from the celloidin, the sections after treating with absolute alcohol were dipped in an alcohol-ether mixture which disisolves away the celloidin.

The bacilli, as soon as they reached the lung, were taken up by epithelial cells lying free in the alveoli and hy cells still attached to the alveolar wall. Despuamation of the epithelial cells som followed the ingestion of the bacilli. At the samo time the bacilli exert a destructive influence upon the elastic: fibres. A result of the injurious action upon the cells and the intercellular substance is a proliferation of the fixed elements, a growth of epithelium occurs as well as of endothelium and comnective tissue colls.

TUBAR(:ULOSIS (ONVHYED BY BOOKS.

A careful study has been made by Mitulescu" in Koch's Institute in regard to the possibility of the spread of tuberculosis by means of library books. A large number of old, soiled books, chicfly works of fiction, were examined. Of the books which had been in use over two years, one third were infected with tubercle bacilli. 'The pages were frequently stuck together by filth and the retained moisture prevented the tubercle bacilli drying. On clean paper drying quickly killed them. None of the books in use less than two years harbored tubercle bacilli, and the covers of the infected books were free from these microorganisms. 'The presence of the tubercle bacilli was determined by inoculating guinen pigs. The pages and covers of the books were thoroughly cleaned with saline solution, the washings centrifugalized and the sediment injected into guinea pigs.

CHRONIC: MYOCARDITIS IN CHILIREN.

Acute myooarditis may develop into chronic inyocarditis, or the latter condition may develop independently of the acute process. The acute infectious discases are the most frequent cause of acute myocarditis, and on account of the greater frefuency of these diseases in ehildren, acute myocarlitis is more common among them than aclults. But it is far from eommon, even among children. In the autopsy records of the Children's Hospital in Viemna during the last ten years are only five cases of acute myocarditis; three followed diphtheria, two occurred after apparently trivial superficial ulcerative processes, in which other signs of sepsis were lacking. (H)servations at the bedside indieate that acute myocarditis, especially after diphtheria, is not rare, and recovery occurs even from the

"Zoitschrifs fur Hygione, 1003, xliv, p. 307. 
severe forms. Under what condition chronie myocarditis is established we do not. know, but it is eertainly one of the rarer diseases in ehildhood, and plays a far loss important rôle than in the carliac pathology of alults. 'This is probably due to the freedom from arterio-sclerosis which so frequently in later life oripples the power of the heart; and ehronic aleoholic intoxication, with its resulting injury to the heart, rarely has to be eonsidered.

'Two cases are reported by Zuppinger. ${ }^{12}$ In the first, signs of acule myocarditis develeped during diphtheria, and death oceurred from chronie myocarditis six weeks later, with symytoms of eardiac insufliciency. The left ventriele measured $2 \mathrm{~cm}$. in thickness. It was dilated and in the wall were many areas of fibrous tissue. In the second case there was great hypertrophy and dilatation and a mural thrombus was situated at the apex of the right ventriele. At this point the wall eomtained fibrous tissue, but it was not demonstrable elsewhere. The boy aged ten hal an attack of moasles four years before and phenmonia one year after the moasles.

THF NATURE OF PRENGUUA ANEMA.

Bloch ${ }^{13}$ has been able to add no experimental cridence in support of the modern theory, so widely held, that pernicious anemia is the result of absorption of toxins from the alimentary tract. Injection of fecal extracts into animals caused only slight anemia. A special toxicity of the urine or blood serum in pernicious ancmia comld not, be demonstrated.

The buceal lesions which flunter regards as an etiologieal factor are secondary to necrosis from subcutaneous hemorrhage and hene withont signifieanere.

\section{Jieportg of Sacietieg.}

\section{THE MEDICAL ASTOCIATION OF THE GREATHR (ITY OF NEW YORK.}

Srated meeting, March 14, 1904. The President, 'THOMAS IS. SA'T'ERTIWAIT', M.D., in the ehair.

Dr. Rober't (Colmanan Kanp read a paper entitled

OBABRVATIONS ON DILATATION OF THE STOMACH ANI) ON (iAstrop'Tosis,

which was illustrated by colored diagrams mate from forty eases in the Manhattan state Hospitals, Ward's Island. It had unfortunately too of ten been the habit., he said, to depend on the examination of the stomarh contents alone, and to neglect the investigation of the motor functions and the position of the stomach itself. The latter is necessary in order to arrive at a correct prognosis and undertake proper treatment.

Atony of the stomach. - This must neressarily first oceur before dilatation of the stomach is produced. Atonia grtstrica may be defined as a loss of tone or contractile power in the museles of the stomach, so that the organ beromes distended and does not contract about its contents, with a resulting motor insuffieiceney. While the dilatation of the stomach in gas-

12 Archiv fur linderhoilkumle, 1903, $\times \times \times 5,1) 381$.

1. Jeutsches Archiv. fur klin. Medizin, Ixxvii, nos. 3 and 4. troptosis is disputed by some, his own observations have shown that dilatation does exist, and with it, necessarily, a varying degree of motor insufficiency.

Dilatation of the Stomach. -.- Roas has demonstrated that an apparently dilated stomach may really be in a condition of eompensatory hypertrophy. It may, therefore, be stated that as long as the functions of the organ are normal, the eondition met with eannot be regarded as pathological. In dilatation the lesser curvature maintains in general its relation to the diaphragm, and this is the differential point between dilatation and gastroptosis. A number of forms of areute dilatation have been deseribed. The first is the result of acute inflammation of the gastrie mucous membrane. It is uncertain whether it depends on pyloric spasm or paralysis of the gastric museles, or on both these causes. The second is a post-operative dilatation, following abdominal section especially. It: would serm to be due to some shook of the sympathetic system, either from the operation or the anesthetic, or possibly, later, from uremia or sepsis. Among the other types of acute dilatation mentioned were the following: In typhoid fever; during attacks of migraine and just preceding epileptice seizures in certain instances; during the course of pneumonia and other pulmonary diseases; in convulsions in infants and young children from over-loading the stomach; in attacks of pseudo-angina pertoris from indiscretions in diet.

('Mromic Dilatation. - Over-feeding and chronic indigestion are undoubtedly eauses of dilatation of the stomaneh in infants and young (hildren. Holt believes intestinal putrefaction exciting convulsions in young children to be an important factor in the production of epilepsy. 1)r. Kemp regards acute dilatation of the stomarch with envulsions as an equally powerful factor, when frequently repeated, in producing the commulsive hahit, and thinks that some cases of epilepsy can cortainly be all ributed to this antse. Moreover, chrouic dilatation of the stomach is itsolf one of the rauses of intestinal putrefaction and disturbance. Amone other etiological factors of rhronic: dilatation are chronir gastritis, atony of the stomach, rapid bolting of food, spatsm of the pylorus due to gastrie ulcer, and benign and malignant pylorie stemosis. Wach oase should receive the special treatment ealbed for by the existing condition. J)r. Kemp washes out the stomach often only in cases in which there is ehronic: gastritis with the production of considerable mucus, or where there is much retained food with fermentation.

Cowstroptosis. - . If gastroplosis exists, some enteroptosis necessarily acoompanies it. The determination of the position of the stomach, in order to secure the best kind of treatment, is of ureat importanere, and frans-illumination of the stomath lo ensiders the ideal method for acrurate diagnosis. The treatment consists in the following measures:

(1) The correction of the functional derangement of the stomach by appropriate diet and medication.

(2) Regulation of the bowels.

(3) Mechanioal support to increase the intra-abdominal fonsion, such as (a) various silk abdomimal supporters; (b) bandages (as the Van Valzah-Hayes method): (c) (iallant's corset: (d) Rose's plaster belt. loe had seen some brilliant results from the last named. Recently he had employed for this belt rubber plaster and moleskin. The sweat evaporates through it on arecount of its loose texture. and it ean be worn for yuite a long time with practionlly no irritation.

Gases at the Mamhatlan State Mospitals, Ward's Isslamd. - 'The drawings I)r. Kemp' presented wore made from forty epilepties in these institutions. The anatomical regions were marked out in blue peneil 